\title{
Hubungan antara Kompetensi Pedagogik dan Kepemimpinan Situasional Kepala Sekolah dengan Keinovatifan Guru SMP Swasta se-Kecamatan Bogor Selatan
}

\author{
Wahardi*, Rita Retnowati**, Eka Suhardi** \\ * Mahasiswa Program Studi Administrasi Pendidikan, Program Pascasarjana \\ ** Staf Dosen Program Studi Administrasi Pendidikan, Program Pascasarjana \\ Universitas Pakuan \\ Bogor, Indonesia
}

Diterima: 10 September 2015. Disetujui: 10 Oktober 2015. Dipublikasikan: Januari 2016

\begin{abstract}
Abstrak
Penelitian ini bertujuan untuk mengetahui hubungan antara Kompetensi Pedagogik dan Kepemimpinan Situasional Kepala Sekolah dengan Keinovatifan Guru Swasta se-Kecamatan Bogor Selatan di Kota Bogor. Penelitian ini merupakan penelitian survei dengan pendekatan korelasional yang terdiri atas dua variabel bebas, yaitu Kompetensi Pedagogik dan Kepemimpinan Situasional Kepala Sekolah serta Keinovatifan Guru sebagai variabel terikat. Penelitian ini dilaksanakan di SMP Swasta se-Kecamatan Bogor Selatan di Kota Bogor pada tahun 2015. Jumlah sampel penelitian sebanyak 112 orang yang diambil secara proportional random sampling dari populasi sebanyak 155. Teknik analisis data penelitian menggunakan teknik analisis statistik korelasi dan regresi sederhana serta korelasi ganda. Pengujian hipotesis dilakukan dengan taraf signifikansi 0,05. Penelitian ini menghasilkan tiga kesimpulan, yaitu: Pertama, terdapat hubungan positif dan sangat signifikan antara Kompetensi Pedagogik dengan Keinovatifan Guru yang ditunjukkan dengan nilai koefisien korelasi $r_{y .1}=0,502$ dan nilai koefisien determinasi $r_{y .1}^{2}=$ 0,245 . Kedua, terdapat hubungan positif dan sangat signifikan antara Kepemimpinan Situasional Kepala Sekolah dengan Keinovatifan Guru. Hal ini ditunjukkan dengan nilai koefisien korelasi $r_{y .2}=0,587$ dan nilai koefisien determinasi $r_{y .2}^{2}=0,345$. Ketiga, terdapat hubungan positif dan sangat signifikan antara Kompetensi Pedagogik dan Kepemimpinan Situasional Kepala Sekolah secara bersama-sama dengan Keinovatifan Guru yang ditunjukkan dengan nilai koefisien korelasi $r_{y .12}=0,692$ dan nilai koefisien determinasi $r_{y .12}^{2}=0,479$. Hasil penelitian menunjukkan bahwa Keinovatifan Guru dapat ditingkatkan melalui Kompetensi Pedagogik dan Kepemimpinan Situasional Kepala Sekolah.
\end{abstract}

(c) 2016 Program Pascasarjana Universitas Pakuan

KATA KUNCI: Keinovatifan Guru, Kompetensi Pedagogik, Kepemimpinan

\section{PENDAHULUAN}

Pentingnya inovasi pendidikan dan inovasi guru telah disadari oleh Pemerintah dan lembaga-lembaga terkait yang peduli terhadap pendidikan. Diadakannya lomba guru berprestasi, secara langsung maupun tidak langsung, dapat memacu dan memicu guru untuk mengembangkan inovasi pembelajaran sehingga dapat meningkatkan 
mutu pendidikan. Lomba-lomba tersebut antara lain: lomba mengajar, membuat karya tulis ilmiah, membuat alat peraga, melakukan penelitian tindakan kelas, dan menggunakan pendekatan pembelajaran yang bervariasi sebagai pengejawantahan keinovatifan guru.

$\begin{array}{lcrr}\text { Seorang } & \text { guru } & \text { yang } & \text { memiliki } \\ \text { keinovatifan } & \text { dalam } & \text { bekerja } & \text { akan } \\ \text { menunjukkan } & \text { keterampilan } & \text { dan } \\ \text { kreativitasnya } & \text { dalam bekerja, } & \text { seperti: }\end{array}$
membuat PTK, membuat RPP, membuat media pembelajaran yang inovatif, selalu merevisi bahan ajar sesuai kebutuhan kegiatan belajar mengajar, sehingga akan berdampak kepada kelancaran kegiatan belajar mengajar di sekolah dan peningkatan kualitas pelayanan kepada peserta didik. Keinovatifan guru juga tercermin dari adanya keinginan untuk mengikuti perkembangan teknologi, khususnya penguasaan terhadap teknologi informasi yang meliputi hardware dan software, penggunaan internet, dan multimedia lainnya yang dapat berguna untuk menunjang proses pembelajaran. Perkembangan teknologi informasi dewasa ini sangatlah pesat. Jika guru tidak peka akan perubahan yang ada, maka perkembangan proses pembelajaran dapat terhambat.

Berdasarkan hasil survei yang dilakukan pada tanggal 7-9 Mei 2015 diperoleh informasi bahwa masih adanya indikasi rendahnya keinovatifan guru terjadi di Kecamatan Bogor Selatan Kota Bogor, yaitu: $53 \%$ Guru yang menggunakan metode pembelajaran yang bervariasi, $25 \%$ Keterlibatan guru dalam merencanakan program sekolah, 40\% Guru yang melaksanakan pembelajaran secara aktif, kreatif, inovatif dan menyenangkan, 57\% Keikutsertaan guru dalam kegiatan peningkatan kompetensinya, seperti kegiatan workshop, pelatihan, seminar, mengikuti lomba-lomba yang berhubungan dengan pendidikan,atau kegiatan lainnya, dan $45 \%$ Guru yang memanfaatkan fasilitas teknologi informasi baik berupa hardware maupun software (microsoft word, microsoft excel, power point) dalam proses belajar mengajar.

Keinovatifan guru adalah aktivitas seorang guru menciptakan ide-ide baru dan mengubahnya menjadi aplikasi yang berguna, dengan proses dan sistem yang baru, yang dapat memberikan manfaat. Dengan indikator: 1) penerimaaan ide baru, 2) penciptaan ide baru, 3) penerapan metode baru dalam pembelajaran, 4) penerapan perubahan dalam pembelajaran, 5) pengevaluasian terhadap perubahan dalam pembelajaran, 6) manfaat/hasil yang dicapai.

Upaya meningkatkan keinovatifan guru diduga berkaitan erat dengan pengembangan kompetensi pedagogik dan optimalisasi implementasi kepemimpinan situasional kepala sekolah secara simultan artinya pada saat kepala sekolah mengoptimalkan penerapan gaya kepemimpinan situasional maka para guru berupaya meningkatkan kompetensi pedagogiknya.

Penelitian sebelumnya yang dilakukan Lucia Christyanti menyatakan adanya hubungan positif yang signifikan antara kepemimpinan situasional dengan keinovatifan guru sebesar $17 \%$. Hasil penelitian lainnya dilakukan Desi Trisnawati, menyatakan adanya kontribusi positif sebesar 21,34\% Kepemimpinan Situasional kepala sekolah dengan Keinovatifan Guru SMA Swasta di Kabupaten Sukabumi.

Berdasarkan latar belakang di atas, perlu adanya kajian lanjut hubungan Kompetensi Pedagogik Guru dan Kepemimpinan Situasional kepala sekolah 
dengan Keinovatifan Guru di SMP Swasta seKecamatan Bogor Selatan. Rumusan masalah dalam penelitian ini adalah: a. Apakah terdapat hubungan antara kompetensi pedagogik dengan keinovatifan guru?; $b$. Apakah terdapat hubungan antara kepemimpinan situasional kepala sekolahmdengan keinovatifan guru?; c. Apakah terdapat hubungan antara kompetensi pedagogik dan kepemimpinan situasional secara bersama-sama dengan keinovatifan guru?

Penelitian ini diharapkan dapat memiliki beberapa manfaat, antara lain: secara teoritis bagi pengembangan keilmuan yang berkenaan dengan Keinovatifan Guru dan menjadi bahan referensi dalam peningkatan Keinovatifan Guru yang terus berkembang secara dinamis, sedangkan secara praktis menjadi sumber pengetahuan bagi guru upaya untuk lebih memahami peran dan fungsinya sebagai tenaga pendidik, dalam rangka meningkatkan Keinovatifan dirinya.

\section{METODE}

Metode penelitian yang digunakan adalah metode survei dengan pendekatan korelasional, yaitu salah satu penelitian dirancang untuk mendapatkan informasi tentang hubungan antara variabel-variabel yang berbeda dalam suatu populasi. Pada penelitian ini, uji reliabilitas yang digunakan untuk mengetahui konsistensi alat ukur adalah menggunakan uji reliabilitas sekali ukur (one shot) dengan menggunakan Teknik Alpha Cronbach.

Subjek penelitian memiliki karakteristik sampel yaitu guru-guru di SMP Swasta Kecamatan Bogor Selatan yang berstatus Guru Tetap Yayasan (GTY). Jumlah responden yang dilibatkan dalam penelitian ini hanya sebanyak 112 orang, dimana 30 responden diluar sampel untuk uji kalibrasi instrumen. Teknik sampling yang digunakan dalam penelitian ini adalah simple random sampling. Jadi, setiap guru-guru di SMP Swasta di Kecamatan Bogor Selatan memiliki kesempatan yang sama untuk dijadikan responden penelitian.

\section{HASIL DAN PEMBAHASAN}

A. Hubungan Antara Kompetensi Pedagogik dengan Keinovativan Guru

Hasil penelitian menunjukkan bahwa terdapat hubungan positif antara Kompetensi Pedagogik dengan Keinovatifan Guru. Hal ini ditunjukkan oleh koefisien korelasi $\left(r_{y .1}\right)$ sebesar 0,502 yang dinyatakan sangat signifikan. kontribusi Kompetensi Pedagogik terhadap Keinovatifan Guru sebesar $24,5 \%$ yang dinyatakan dengan nilai koefisien determinasi $\left(r_{\text {y.1 }}^{2}\right)$ sebesar 0,245. Koefisien korelasi parsial Kompetensi Pedagogik (dengan variabel Kepemimpinan Situasional dikendalikan) adalah sebesar 0,453 yang dinyatakan sangat signifikan.

Berdasarkan persamaan regresi linier sederhana $\hat{Y}=114,70+1,58 X_{1}$, diprediksi bahwa setiap kenaikan satu unit skor Kompetensi Pedagogik akan menyebabkan kenaikan 1,58 unit skor Keinovatifan Guru pada konstanta 114,70 . Hasil penelitian ini menyimpulkan bahwa Kompetensi Pedagogik yang dimiliki memberikan kontribusi positif yang berpengaruh nyata terhadap Keinovatifan Guru.

Pada hakikatnya Kompetensi Pedagogik adalah kemampuan guru dalam mengelola kegiatan pembelajaran sehingga peserta didik dapat mengaktualisasikan potensi yang dimilikinya secara maksimal.

$$
\text { Kompetensi Pedagogik dalam }
$$
penelitian ini menggunakan 8 indikator yaitu: (1) wawasan/landasan kependidikan, (2) pemahaman terhadap peserta didik, (3) 
pengembangan kurikulum dan perancangan pembelajaran, (4) pelaksanaan pembelajaran dialogis, (5) pemanfaatan teknologi pembelajaran, (6) pelaksanaan evaluasi hasil belajar, (7) pemanfaatan hasil penilaian dan evaluasi untuk kepentingan pembelajaran, dan (8) pelaksanaan tindakan reflektif untuk peningkatan kualitas pembelajaran. Indikator ini menjadi tolak ukur tinggi rendahnya Kompetensi Pedagogik dalam meningkatkan Keinovatifan Guru.

Adanya nilai rata-rata yang bervariasi dari kedelapan indikator ini menunjukkan masih terdapatnya beberapa masalah dari variabel Kompetensi Pedagogik. Hal ini dapat dilihat dari rata-rata nilai unsur per indikator yang masih terdapat nilai yang belum memenuhi harapan, seperti terlihat pada indikator evaluasi hasil pembelajaran dengan nilai rata-rata 0,87 atau masuk dalam kategori cukup dan adanya indikator yang masih lemah yaitu indikator pelaksanaan pembelajaran dengan nilai rata-rata 0,33. Sedangkan untuk keinovatifan guru, unsur yang teridentifikasi masih belum sesuai terdapat pada indikator ke-5 yaitu evaluasi perubahan dengan rata-rata unsur pembentuknya mencapai 3,74 dan termasuk dalam kategori cukup.

Berdasarkan hasil penelitian dapat disimpulkan bahwa Kompetensi Pedagogik memberikan kontribusi yang sangat signifikan terhadap keinovatifan guru. Hal ini mendukung penyataan Schiffman dan Kanuk yang menjelaskan keinovatifan (innovativeness) adalah sifat kepribadian yang melekat pada individu yaitu mereka yang cenderung menjadi orang pertama mencoba berbagai produk, jasa, atau praktik baru karena respon pasar yang akhirnya akan menentukan keberhasilan produk atau jasa baru tersebut. Seorang guru dapat menggali keinovatifannya dengan berbagai

cara, antara lain melalui; pengalamanpengalamannya sendiri, mencari tahu dari berbagai media yang ada. Guru yang memiliki keinovatifan akan terus menggali potensi dirinya dan yang terpenting guru juga harus merubah persepsinya untuk dapat menerima dan menciptakan ide-ide baru dalam dirinya.

Adanya tuntutan perubahanperubahan dalam penggunaan metode mengajar, strategi belajar mengajar, maupun sikap dan karakteristik guru dalam mengelola pembelajaran. Untuk itu, guru harus memiliki kompetensi pedagogik sehingga mengelola pembelajaran yang memberikan rangsangan kepada peserta didik agar mau belajar karena memang peserta didiklah subjek utama dalam belajar.

Dengan demikian temuan fakta dan data dalam analisis penelitian ini semakin mendukung temuan-temuan terdahulu mengenai adanya hubungan yang kuat antara Kompetensi Pedagogik terhadap Keinovatifan Guru, baik secara langsung ataupun tidak langsung.

B. Hubungan Antara Kepemimpinan Situasional Kepala Sekolah dengan Keinovatifan Guru

Hasil penelitian menunjukkan bahwa terdapat hubungan positif antara Kepemimpinan Situasional Kepala Sekolah dengan Keinovatifan Guru. Hal ini ditunjukkan oleh koefisien korelasi (ry.2) sebesar 0,587 yang dinyatakan signifikan. Kontribusi Kepemimpinan Situasional Kepala Sekolah terhadap Keinovatifan Guru sebesar $34,5 \%$ yang dinyatakan dengan nilai koefisien determinasi $\left(r_{y .2}^{2}\right)$ sebesar 0,345. Koefisien korelasi parsial Kepemimpinan Situasional Kepala Sekolah (dengan variabel Kompetensi Pedagogik dikendalikan) adalah 
sebesar 0,552 yang dinyatakan signifikan pada taraf $\alpha=0,05$.

Pola hubungan antara variabel Kepemimpinan Situasional Kepala Sekolah dengan variabel Keinovatifan Guru dinyatakan dengan persamaan regresi linier sederhana $\hat{Y}=80,30+0,52 X_{2}$, diprediksi bahwa setiap kenaikan satu unit skor Kepemimpinan Situasional Kepala Sekolah akan menyebabkan kenaikan 0,52 unit skor Keinovatifan Guru pada konstanta 80,30. Terdapatnya hubungan yang positif antara Kepemimpinan Situasional Kepala Sekolah dengan Keinovatifan Guru menunjukkan bahwa peran Kepemimpinan Situasional Kepala Sekolah akan sangat membantu tercapainya Keinovatifan Guru.

Hakikat Kepemimpinan Situasional Kepala Sekolah merupakan perilaku kepala sekolah dalam berinteraksi dengan guru dalam melaksanakan tugas dan tanggung jawabnya untuk dapat mengarahkan, memengaruhi dan menggerakkan guru dalam bekerja dengan memperhatikan situasi kematangan para guru agar guru bersikap mandiri terutama memecahkan masalah-masalah sebagai upaya pencapaian tujuan organisasi.

Kepemimpinan Situasional Kepala Sekolah dalam penelitian ini menggunakan 4 indikator yang terdiri dari: 1) pemberian petunjuk kepada guru, 2) pembimbingan guru, 3) pelibatan diri (partisipasi) dalam pelaksanaan tugas guru, 4) Pemberian dukungan kepada guru.

Analisis studi terdahulu mengenai analisis hubungan Kepemimpinan Situasional Kepala Sekolah terhadap Keinovatifan Guru menyatakan bahwa peningkatan Kepemimpinan Situasional Kepala Sekolah akan diikuti dengan peningkatan Keinovatifan Guru di sekolah. Hasil penelitian tersebut menyatakan
Kepemimpinan Situasional Kepala Sekolah berperan dalam menstimulasi keinovatifan dan perubahan dengan menerapkan fleksibilitas, memenangkan kompetensi dengan sekolah lain dan yang terus menerus memiliki produk dan jasa yang inovatif untuk menjadi sekolah unggulan. Hal ini sejalan dengan pernyataan oleh Anne Gold and Jeniffer Evans yaitu pemahaman, power dan komitmen kepala sekolah memiliki efek langsung baik pada guru-guru maupun pada peserta didik melalui gaya kepemimpinan disesuaikan dengan situasi dan kondisi kematangan bawahannya dapat meningkatkan dampak positif terhadap kinerja organisasi sekolah.

Dengan demikian temuan fakta dan data dalam analisis penelitian ini semakin mendukung temuan-temuan terdahulu mengenai adanya hubungan yang kuat antara Kepemimpinan Situasional Kepala Sekolah terhadap Keinovatifan Guru baik secara langsung ataupun tidak langsung.

C. Hubungan Antara Kompetensi Pedagogik $\left(X_{1}\right)$ dan Kepemimpinan Situasional Kepala Sekolah $\left(X_{2}\right)$ Secara Bersamasama dengan Keinovatifan Guru (Y)

Model hubungan antara Kompetensi Pedagogik dan Kepemimpinan Situasional Kepala Sekolah secara bersama-sama dengan Keinovatifan Guru dapat dinyatakan dalam persamaan regresi linier ganda $\hat{Y}=$ $63,16+1,20 X 1+0,44 X_{2}$, artinya apabila Kompetensi Pedagogik $\left(X_{1}\right)$ dan nilai Kepemimpinan Situasional Kepala Sekolah (X2) meningkat sebesar 1 unit, maka nilai Keinovatifan Guru (Y) akan meningkat sebesar 1,64 unit pada arah yang sama dengan konstanta 63,16 . Persamaan linier regresi ganda $\hat{Y}=63,16+1,20 X_{1}+0,44 X_{2}$ dapat digunakan untuk memprediksi skor 
Keinovatifan Guru apabila skor Kompetensi Pedagogik dan skor Kepemimpinan Situasional Kepala Sekolah diketahui. Kekuatan hubungan antara Kompetensi Pedagogik dan Kepemimpinan Situasional Kepala Sekolah secara bersama-sama dengan Keinovatifan Guru. Hal ini ditunjukkan oleh koefisien korelasi $\left(r_{y .12}\right)$ sebesar 0,692 yang dinyatakan sangat signifikan setelah diuji dengan uji $F$. kontribusi Kompetensi Pedagogik dan Kepemimpinan Situasional Kepala Sekolah secara bersama-sama terhadap Keinovatifan Guru sebesar $47,9 \%$ yang dinyatakan dengan nilai koefisien determinasi $\left(r_{\text {y.12 }}^{2}\right)$ sebesar 0,479 .

Hasil penelitian menunjukkan bahwa terdapat hubungan positif antara Kompetensi Pedagogik dan Kepemimpinan Situasional Kepala Sekolah secara bersamasama dengan Keinovatifan Guru, artinya makin efektif Kompetensi Pedagogik dan makin kuat Kepemimpinan Situasional Kepala Sekolah secara bersama-sama, maka makin tinggi Keinovatifan Guru.

Upaya peningkatan keinovatifan guru di sekolah tentunya tidak terlepas dari tuntutan kepemimpinan kepala sekolah. Kepemimpinan situsional kepala sekolah dikatakan efektif karena proses mempengaruhi dan menggerakkan bawahan para guru dan karyawan pada sekolah lebih cenderung menyesuaikan dengan situasisituasi tertentu, sehingga mampu menciptakan environment kerja sekolah yang kondusif dengan cara kooperatif, membangun trust, free of stress atmosphere, instruksi yang jelas, tidak diskriminatif antara senior dan junior.

Kepemimpinan situasional kepala sekolah akan menjadikan guru termotivasi untuk bekerja lebih kreatif untuk meningkatkan kompetensi dirinya. Adanya kompetensi pedagogik guru dan gaya kepemimpinan kepala sekolah yang ditingkatkan secara bersamaan, maka keinovatifan guru lebih meningkat. Tanpa kepemimpinan kepala sekolah, proses pelaksanaan tugas guru tidak akan berjalan dengan antusias, terarah, lancar, dan efektif. Dengan demikian dapat dikatakan bahwa pengejewantahan kepemimpinan kepala sekolah menjadi kunci keberhasilan bagi perwujudan keinovatifan guru di sekolah.

Pernyataan ini menunjukkan bahwa Kompetensi Pedagogik dan Kepemimpinan Situasional Kepala Sekolah memberikan kontribusi positif yang berpengaruh nyata terhadap Keinovatifan Guru.

Berdasar data penelitian dari seluruh variabel-variabel ditemukan adanya beberapa indikator yang masih belum memenuhi harapan dari masing-masing variabel penelitian yaitu:

a. Keinovatifan Guru, unsur yang masih lemah adalah pada indikator ke-5 yaitu evaluasi perubahan.

b. Kompetensi Pedagogik, unsur unsur yang masih lemah adalah pada indikator ke-3 dan ke-4, yaitu penerapan pelaksanaan pembelajaran dan teknologi pembelajaran.

c. Kepemimpinan Situasional Kepala Sekolah, unsur yang masih lemah adalah pada indikator ke-2 yaitu pembimbingan guru (coaching).

\section{PENUTUP}

Berdasarkan hasil pengujian hipotesis dan pembahasannya yang telah diuraikan di atas dapat disimpulkan bahwa: 1. Terdapat hubungan positif dan sangat signifikan antara Kompetensi Pedagogik dengan Keinovatifan Guru dan Kompetensi Pedagogik memberikan kontribusi terhadap Keinovatifan Guru sebesar 24,5\%; 2. 
Terdapat hubungan positif dan sangat signifikan antara Kepemimpinan Situasional Kepala Sekolah dengan Keinovatifan Guru dan kontribusi Kepemimpinan Situasional Kepala Sekolah terhadap Keinovatifan Guru sebesar $34,5 \%$; 3 . Terdapat hubungan positif dan sangat signifikan antara Kompetensi Pedagogik dan Kepemimpinan Situasional Kepala Sekolah secara bersama-sama Keinovatifan Guru. Kompetensi Pedagogik dan Kepemimpinan Situasional Kepala Sekolah secara bersama-sama memberikan kontribusi terhadap Keinovatifan Guru sebesar 47,9\%.

Beberapa saran yang diajukan terkait hasil penelitian ini adalah: 1. Kepala Sekolah seharusnya mengoptimalisasi implementasi gaya kepemimpinan situasional di sekolah dapat diwujudkan dengan menefekktifkan dan mengintensifkan pelaksanaan pembimbingan (coaching); 2. Guru dapat meningkatkan Kompetensi pedagogiknya melalui pelaksanaan pembelajran dialogis dan merefleksikan hasil pembelajaran secara efektif; 3. Bagi Kepala Dinas Pendidikan, peningkatan mutu lembaga pendidikan melalui meningkatkan keinovatifan guru bukan hanya tugas para guru dan kepala sekolah, akan tetapi Pemerintah melalui Dinas Pendidikan juga berkewajiban untuk mewujudkan hal tersebut.

\section{DAFTAR PUSTAKA}

Angelo, K \& Williams, B. (2008). Management A Practical Introduction, Third Edition. New York: Mc Graw Hill Education

Anne, G \& Evans, J. (2005). Reflecting on School Management. London: Falmer Press

Arikunto, S. (2010). Prosedur Penelitian Suatu Pendekatan Praktik. Jakarta: PT. Rineka Cipta

Bertocci, L. (2009). Leadership in Organizations There is a Difference between Leaders and Managers, United Kingdom: University Press Of America
Brent, D., Ellison, L \& Bowring-Carr. (2005). School Leadership in the 21st Century Second edition. London and Newyork: Roultledge Falmer

Carrie -Fisch, R., Greenfield, P., Trumbull, E., Keller, H., \& Quiroz, B. (2010). Innovations in Educational Psychology, ed. David D. Preiss and Robert J. Sternberg. New York: Springer Publishing Company

Christyanti, L. Hubungan antara Kepemimpinan Situasional Kepala Sekolah dan Motivasi berprestasi dengan Keinovatifan Guru SMA Negeri Sub Rayon 03 Kota Bekasi. Tesis PPs UNPAK: Tidak diterbitkan

Denim, S. (2010). Pedagogi, Andragogi, dan Heutagogi. Bandung: Alfabeta

Don, H \& Slocum, J. (2011). Organizational Behavior, 13th Edition. USA: South-Western Cengage Learning

Hamzah, U.B. (2011). Belajar Dengan Pendekatan PAIKEM, Cetakan Kedua. Jakarta : PT. Bumi Aksara

Hawkins, D \& Motherbaugh, D. (2010). Consumer Behavior Building Marketing Strategy. New York: McGraw-Hill Companies, Inc

Hidayatullah, F. (2009). Guru Sejati Membangun Insan Berkarakter Kuat dan Cerdas. Surakarta: Yuma Pustaka

Jack, W., Wallace, J., Zeffane, R., Schermerhorn, J.R., Hunt, J.G \& Osborn, R. (2001). Organisational Behaviour a Global Perspective. Milton: John Wiley \& Sons Australia, Ltd

Jerald, G \& Baron, R. (2010). Managing Behavior in Organization, Ninth Edition. Pearson International Edition

Mulyasa, E. (2007). Menjadi Guru Profesional. Bandung: PT. Remaja Rosdakarya

Peter, E \& Weindling, D. (2004). Understanding School Leadership. London: Chapman Publishing

Prasetyo, B dan Jannah, L. (2005). Metode Penelitian Teori dan Aplikasi. Jakarta: Raja Grafindo Persada

Retnowati, R. (2008). Metodologi Penelitian. Program Pascasarjana Universitas Pakuan: Tidak Diterbitkan

Robbins, S \& Judge, T. (2010). Organizational Behavior. England: Pearson

Sadulloh, U. (2010). Pedagogik (Ilmu Mendidik). Bandung: Alfabeta

Sa'ud, U.S (2008). Inovasi Pendidikan. Bandung: Alfabeta 
Jurnal Manajemen Pendidikan Vol. 4 No. 1, Januari 2016

Sagala, S. (2006). Administrasi Pendidikan Kontemporer. Bandung: CV Alfabeta

Sedarmayanti. (2011). Membangun Dan Mengembangkan Kepemimpinan Serta Meningkatkan Kinerja Untuk Meraih Keberhasilan. Bandung: PT Refika Aditama

Somantri, A dan Muhidin, S. (2006). Aplikasi Statistika dalam Penelitian. Bandung: CV Pustaka Setia.

Sugiyono. (2013). Metode Penelitian Pendidikan; Pendekatan Kuantitatif, Kualitatif, $R \& D$. Bandung: Alfabeta

Trianto \& Tutik. (2007). Sertifikasi Guru dan Upaya Peningkatan Kualifikasi Kompetensi dan Kesejahteraan. Jakarta: Prestasi Pustaka 